\title{
ANALISIS BUKU SISWA MATEMATIKA SMA DARI INDONESIA DAN CHINA PADA MATERI PELUANG DAN STATISTIK
}

\author{
Aditya Purnama ${ }^{1}$, Tommy Tanu Wijaya ${ }^{1}$ Senja Noviani Dewi ${ }^{2}$, Zulfah Zulfah $^{3}$ \\ ${ }^{1}$ Guangxi Normal University, China \\ ${ }^{2}$ IKIP Siliwangi, Indonesia \\ ${ }^{3}$ Universitas Pahlawan Tuanku Tambusai, Indoneisa \\ 2890174293@qq.com
}

\begin{abstract}
Textbooks play an important role in improving mathematical abilities and student learning achievement. This study aims to analyze the content of textbook that are widely used in Indonesia and China. The object of this research is the material of probability and statistics in high school grade 12. The research method used in this research is descriptive qualitative. The textbook is analyzed from several important aspects such as the composition of the opportunity material and statistics, the division of subject hours and the analysis carried out on the practice questions. The results of this study shown that there are 14 subject hours in Indonesia more than in China. The composition of probability and statistical material in Indonesia is more than the composition of probability and statistics materials in Indonesia. The number of practice questions in the Indonesian textbook is more than the Chinese textbook. But there are more types of questions applying and reasoning to the Chinese textbook than in the Indonesian textbook. The conclusion of this study shows that students in Indonesia have more time to learn probability and statistics material. As well as students in Indonesia are used to many practice questions. Meanwhile students in China focus more on important points and improve students' high order thinking ability. hoped that this research can be taken into consideration in the preparation of a textbook in the next curriculum in two countries.
\end{abstract}

Keywords: analysis textbook, probability and statistics, senior high school material, Indonesian textbook, chinese textbook

\begin{abstract}
Abstrak
Buku pelajaran menjadi salah satu peranan penting dalam meningkatkan kemampuan matematis dan hasil belajar siswa. penelitian ini bertujuan untuk menganalisis konten pada buku cetak yang banyak dipakai di Indonesia dan china. Objek pada penelitian ini adalah materi peluang dan statistik pada SMA kelas 12. Metode penelitian yang dipakai pada penelitian ini adalah deskriptif kualitatif. Textbook dianalisis dari beberapa aspek penting seperti susunan materi peluang dan statistic, pembagian jam mata pelajaran dan analisis yang dilakukan pada soal latihan. Hasil pada penelitian ini menunjukkan bahwa jam mata pelajaran di Indonesia lebih banyak 14 jam mata pelajaran dibanding di china. Susunan materi peluang dan statistik di Indonesia lebih banyak di banding susunan materi peluang dan statistic di Indonesia. Jumlah soal latihan pada Indonesian textbook lebih banyak dibanding chinese textbook. Tetapi jumlah type soal applying dan reasoning pada chinese textbook lebih banyak dibanding Indonesia textbook. siswa di Indonesia terbiasa dengan banyak latihan soal. Sedangkan siswa di china lebih fokus pada poin-poin penting dan meningkatkan kemampuan high order thinking (HOT) siswa. diharapkan penelitian ini dapat menjadi bahan pertimbangan pada penyusunan textbook pada kurikulum selanjutnya pada dua Negara.
\end{abstract}

Kata kunci: analisis buku cetak, peluang dan statistik, materi SMA, Indonesian textbook, chinese textbook

\section{PENDAHULUAN}

Matematika masih menjadi fokus utama pelajaran yang harus dikuasai oleh siswa (Wijaya, Purnama, \& Tanuwijaya, 2020). setiap 3 tahun sekali, ada test kemampuan matematis siswa yaitu PISA (Andini, Mulyani, Wijaya, \& Supriyati, 2018). PISA diadakan 3 tahun sekali. Ini dapat menjadi acuan kemampuan matematis siswa di Indonesia dengan Negara lain (Fachrudin, Widadah, \& Kusumawati, 2019). berdasarkan data yang dapat di lihat pada gambar 1. Dapat dilihat dari seluruh ilmu bidang studi yang diteliti, Indonesia mengalami penurunan score rata-rata dibanding tahun 2015 . 
Fokus pada bidang matematika, Dapat dilihat pada kolom grafik mathematics, score poin kemampuan literasi matematis siswa pada tahun 2015 terjadi peningkatan dibandingkan dengan hasil PISA pada tahun 2012. Hasil PISA tahun 2012 berjumlah 375 dan pada tahun 2015 naik 9 poin menjadi 386 poin. Tetapi, yang menjadi perhatian kita dan poin penting adalah. Hasil PISA tahun 2018 kembali mengalami penurunan pada rata-rata score poin 379. hal ini manjadi tugas kita semua sebagai murid, guru dan yang bekerja pada bidang pendidikan. untuk meningkatkan kemampuan matematis siswa di berbagai aspek. Dengan harapan pendidikan menuju kearah yang lebih baik lagi. PISA test selanjutkan akan diadakan pada tahun 2022. Para siswa masih bisa bersiap-siap untuk mendapatkan score terbaik pada test PISA ini.

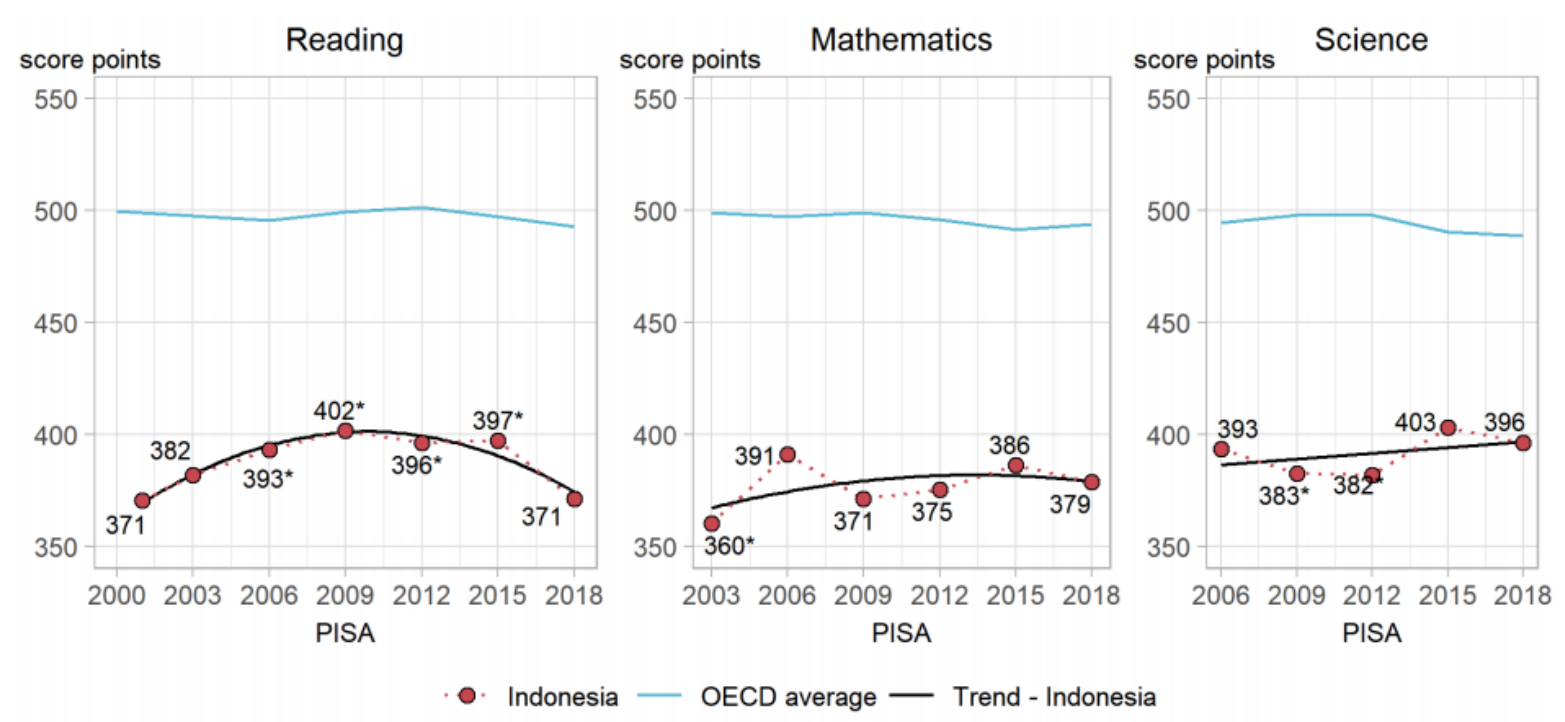

Gambar 1. Hasil Score Literasi Matematis PISA 2018.

Meningkatkan kemampuan matematis siswa dapat melalui banyak cara. Banyak penelitian yang telah dilakukan untuk meningkatkan kemampuan matematis siswa. saya satunya adalah menggunakan berbagai metode atau pendekatan pembelajaran (Hutajulu, Wijaya, \& Hidayat, 2019; Yi, Ying, \& Wijaya, 2019), penggunaan media pembelajaran berbasis teknologi untuk meningkatkan kemampuan hardskill dan softskill siswa(Wijaya, Ying, Cunhua, \& Zulfah, 2020; Wijaya, Ying, \& Purnama, 2020b), pengembangan media pembelajaran menggunakan dynamic mathematics software untuk membantu para siswa memahami konsep dasar materi matematika (Tan, Zou, Wijaya, Suci, \& Dewi, 2020; Wijaya, Sukma, Purnama, \& Tanuwijaya, 2020; Wijaya, Ying, \& Purnama, 2020a). semua cara cara yang telah dilakukan peneliti sebelumnya adalah untuk meningkatkan kemampuan matematis siswa. berusaha keras agar metode metode atau pendekatan yang diberikan dapat meningkatkan kemampuan matematis siswa di berbagai aspek. hal terpenting adalah untuk meningkatkan kemampuan berpikir HOTS dan pemahaman konsep matematika yang mendalam. Sehingga siswa dapat menggunakannya pada kehidupan sehari-hari (Dini, Wijaya, \& Sugandi, 2018; Kulsum, Hidayat, Wijaya, \& Kumala, 2019). tetapi ada hal yang tidak kalah Penting untuk meningkatkan kemampuan matematis siswa. yaitu penggunaan textbook yang digunakan oleh siswa 
Analisis Buku Siswa Matematika SMA dari Indonesia dan China Pada Materi Peluang dan Statistik, Aditya Purnama,

(Yang, Tseng, \& Wang, 2017).

Di berbagai Negara termasuk Indonesia, textbook masih menjadi salah satu acuan sebagai sumber belajar siswa. textbooks juga menunjukkan effect yang cukup besar pada kegiatan belajar mengajar dan dasar guru mengajar di kelas(Yang \& Sianturi, 2017). Beberapa fungsi textbook dalam kegiatan belajar mengajar antara lain adalah; membantu guru untuk menjelaskan materi, sebagai bahan latihan soal siswa, mengarahkan siswa dalam memahami suatu materi matematika (Takeuchi \& Shinno, 2020).

Peluang dan statistika adalah materi wajib yang harus dipelajari oleh siswa sekolah menengah atas (SMA) di Cina, dan juga merupakan konten penting dari mata pelajaran matematika di berbagai negara (Faelasofi, 2017; Ramelan \& Wijaya, 2019). Pelajaran peluang dan statistik membantu orang membuat keputusan yang lebih baik tentang peristiwa yang tidak diketahui dengan mengumpulkan, menyortir, menganalisis, dan menjelaskan kemungkinan fenomena yang tidak pasti. Peluang dan statistik, yang berasal dari pemecahan masalah praktis, telah berkembang sangat pesat dalam beberapa tahun terakhir, tidak hanya memainkan peran penting dalam bidang matematika tradisional (seperti penggunaan metode probabilitas untuk melengkapi pembuktian beberapa teorema matematika di SMP dan SMA), tetapi juga dalam ilmu pengetahuan alam dan masyarakat. Sains dan bidang lain memiliki cakupan aplikasi yang luas. Oleh karena itu, menggunakan statistik probabilitas sebagai tujuan penelitian dan membandingkan bagian-bagian yang sesuai dari buku teks matematika sekolah menengah di berbagai negara tidak hanya dapat menemukan persamaan dan perbedaan dalam karakteristik kompilasi buku teks dan tingkat kesulitan komprehensif dari mata kuliah yang diajarkan, tetapi juga Mengungkap perbedaan konsep pendidikan bahan ajar.

Melihat pentingnya penggunaan textbook untuk membantu siswa dalam memahami materi dan konsep dasar pada pelajaran matematika serta berdasarkan latar belakang untuk meningkatkan kemampuan matematis khususnya pada mata pelajaran peluang dan statistic. Pada penelitian ini akan dilakukan analisis perbandingan textbook Indonesia dan china untuk melihat kelebihan antara kedua buku. Hasil analisis pada penelitian ini dapat digunakan pengembangan textbook di Indonesia pada saat revisi kurikulum selanjutnya. Serta menjadi saran para guru saat mengajar materi peluang dan statistic serta menyajikan soal latihan kepada siswa.

\section{METODE}

Penelitian ini menggunakan metode deskriptif kualitatif untuk membandingkan materi peluang dan statistik dari 2 negara yaitu china dan Indonesia. Objek penelitian pada penelitian ini adalah peluang dan statistik konten buku teks versi China dan Indonesia. Buku teks yang dipilih merupakan buku teks yang banyak digunakan dan buku terbaik di negaranya masing-masing, spesifikasi textbook dapat dilihat pada Tabel 1. Buku cetak matematika dari penerbit yudhistira banyak digunakan oleh sekolahsekolah swasta maupun negeri di kota-kota besar di Indonesia. Buku pelajaran terbitan yudhistira juga 
banyak dipakai sebagai sumber referensi (Hidayat, 2017). Sedangkan buku pelajaran matematika versi china menggunakan pendidikan rakyat press. Buku terbitan ini yang paling banyak dipakai di sekolahsekolah di china sebagai sumber belajar yang baik (Yang et al., 2017).

\section{Tabel 1.}

textbook versi China dan Indonesia

\begin{tabular}{|c|c|c|c|}
\hline Negara & Penerbit & Judul Buku & $\begin{array}{c}\text { Tahun } \\
\text { terbitan }\end{array}$ \\
\hline \multirow[t]{2}{*}{ China } & \multirow[t]{2}{*}{$\begin{array}{l}\text { Pendidikan } \\
\text { rakyat Press }\end{array}$} & $\begin{array}{l}\text { Buku teks eksperimental standar kurikulum sekolah } \\
\text { menengah umum ( matematika wajib) }\end{array}$ & $\begin{array}{ll}2014 & \text { edisi } \\
\text { ke } 2 & \end{array}$ \\
\hline & & $\begin{array}{l}\text { Buku teks eksperimental standar kurikulum sekolah } \\
\text { menengah umum (matematika minat) }\end{array}$ & 2014 edisi 2 \\
\hline \multirow[t]{2}{*}{ Indonesia } & \multirow[t]{2}{*}{ Yudhistira } & Jelajah Matematika SMA Kelas XII Program Wajib & 2018 \\
\hline & & Jelajah Matematika SMA Kelas XII Peminatan MIPA & 2018 \\
\hline
\end{tabular}

Pada penelitian ini, dilakukan analisis pada beberapa poin penting pada materi peluang dan statistik di kedua Negara. Poin poin analisis diadopsi dari beberapa penelitian yang telah dilakukan oleh peneliti sebelumnya. Poin poin analisis tersebut antara lain adalah;

a. Analisis susunan sub bab

b. Analisis konten sub bab

c. Analisis penyajian bentuk soal latihan

Selain poin poin analisis diatas, peneliti juga menambahkan poin analisis pada jumlah jam mata pelajaran pada materi peluang dan statistic untuk mengetahui perbedaan kurikulum di dua Negara. pada saat suatu sub bab pada materi lebih banyak. Maka dapat diinterpretasikan bahwa kurikulum tersebut mempunyai banyak fokus pada sub bab tersebut atau sub bab tersbut lebih penting dibanding sub bab lainnya.

Acuan analisis bentuk soal pada penelitian ini dinilai dengan assessment framework TIMSS 2019 yang pada intinya membahas tentang kemampuan penalaran matematis ssiwa serta kemampuan siswa dalam menerapkannya dapat kehidupan sehari-hari. Analisis dilakukan dengan mendeskripsikan dan mengelompokan soal berdasarkan domain kognitif assessment framework TIMSS 2019 yang terdiri dari knowing (pengetahuan), applying (penerapan) dan reasoning (penalaran).

Bagian ini berisi sub bagian dari Metode. Penulis dapat menggunakan style heading 2 untuk sub judul. Penulis dapat menggunakan style heading ini untuk di sub judul di bagian lain di dalam manuscript ini. 


\section{HASIL}

Analisis Susunan Sub Bab Materi Peluang dan Statistik

setiap Negara mempunyai kurikulum sendiri terhadap mata pelajaran. Kurikulum mengatur berbagai aspek dalam kegiatan belajar mengajar seperti susunan pembelajaran, banyaknya jam mata pelajaran, tujuan pembelajaran, standart kompentensi, dan hal penting lainnya yang berkaitan dengan kegiatan belajar mengajar. oleh karena itu, setiap Negara mempunyai susunan dan pembahasan yang berbeda pada suatu materi. pada tabel 2 dapat dilihat perbedaan susunan dan sub bab pada materi peluang dan statistik antara chinese textbook dan Indonesian textbook.

\section{Tabel 2.}

Susunan dan Sub Bab Materi Peluang dan Statistic di China

\begin{tabular}{|l|l|l|l|}
\hline \multicolumn{1}{|c|}{ Materi } & Sub-bab & \multicolumn{1}{|c|}{ PEPB (China) } & \multicolumn{1}{|c|}{ Erlangga (Indonesia) } \\
\hline Matematika wajib & Statistik & pengambilan sample acak & Istilah- istilah dalam statistika \\
\hline & & sample perkiraan populasi & Penyajian data statistika \\
\hline & & korelasi variable & Ukuran pemusatan data \\
\hline & & & Ukuran letak data \\
\hline & Peluang & Peristiwa dan kejadian & Ukuran penyebaran data \\
\hline & & Profil classic (kuno) & Kaidah pencacahan \\
\hline & & Nomor acak & Permutasi \\
\hline & & $\begin{array}{l}\text { Penerapan peluang dalam kehidupan } \\
\text { sehari }\end{array}$ & Peluang kejadian saling bebas \\
\hline & & $\begin{array}{l}\text { Variabel acak diskrit dan urutan } \\
\text { distribusinya }\end{array}$ & Veluariabel acak \\
\hline Matematika minat & Peluang bersyarat dan & Distribusi binomial \\
\hline & & $\begin{array}{l}\text { Probabilitas } \\
\text { Kemandirian Peristiwa }\end{array}$ \\
\hline & & Karakteristik numerik variabel acak & Pengujian hipotesis \\
\hline & Statistik & Independence Test & Populasi dan sampel \\
\hline & & Regression analysis & \\
\hline
\end{tabular}

Berdasarkan analisis yang dilakukan oleh peneliti pada matematika wajib pada materi peluang dan statistic yang dapat dilihat pada tabel. Susunan Sub bab pada Indonesian textbook lebih banyak dibandingkan susunan pada chinese textbook. Indonesian textbook mempunyai total 11 subbab pada buku matematika wajib sedangkan chinese textnook mempunyai 7 sub bab pada buku matematika wajib. Sedangkan pada buku matematika peminatan, chinese textbook mempunyai 6 sub bab dan Indonesian textbook mempunyai 4 sub bab. berbedaan tersebut dapat dikaitkan dengan jam mata pelajaran. Jam mata pelajaran di Indonesia pada materi peluang dan statistic lebih banyak 14 jam dibandingkan jam mata pelajaran di China. sehingga pembahasan pada Indonesian textbook lebih banyak yang dapat membuat siswa mempunyai banyak waktu untuk mendapatkan konsep dasar pada materi peluang dan statistik. 


\section{Analisis type soal pada peluang dan statistic}

Cara penyajian soal dapat mempengaruhi kualitas dan cara berpikir siswa. perbedaan cara penyajian soal menjadi suatu peluang bagi siswa untuk mengembangkan kemampuan reasoning matematis siswa. secara type jumlah pembahasan soal baik pada pembahasan contoh soal maupun type latihan soal pada Indonesian textbook lebih banyak dibandingkan chinese textbook. Pembagian type soal yang lebih lengkap dapat dilihat pada table 3. Pada cognitive domain knowing, persentase soal pada pembahasan contoh soal Indonesian textbook lebih banyak dari pada chinese textbook. Dengan berbedaan presentasi $20.80 \%$. Pada cognitive domain applying, jumlah soal pada pembahasan contoh soal pada chinese textbook lebih banyak dibandingkan Indonesian textbook dengan berbedaan persentase sebesar $14.90 \%$. pada cognitive domain tingkat tinggi yaitu reasoning, banyaknya pembahasan contoh soal pada chinese textbook juga lebih banyak dibandingkan dengan Indonesian textbook. Diketahui selisih persentase pada type soal reasoning pada pembahasan contoh soal sebesar $6.02 \%$.

Tabel 3.

Type Soal Pada Materi Peluang dan Statistic

\begin{tabular}{|l|l|l|l|l|l|}
\hline Pembagian soal latihan & Cognitive & \multicolumn{2}{|c|}{ Jumlah soal } & \multicolumn{2}{c|}{ Presentase soal } \\
\hline \multirow{2}{*}{$\begin{array}{l}\text { Type pembahasan } \\
\text { contoh soal }\end{array}$} & domain & Chinese textbook & Indonesian textbook & china & Indonesia \\
\cline { 2 - 7 } & applying & 27 & 41 & $36.54 \%$ & $57.34 \%$ \\
\cline { 2 - 7 } & reasoning & 6 & 26 & $51.92 \%$ & $37.02 \%$ \\
\hline \multirow{3}{*}{ Type latihan soal } & Knowing & 6 & 4 & $11.54 \%$ & $5.52 \%$ \\
\cline { 2 - 7 } & applying & 44 & 25 & $11.54 \%$ & $70.42 \%$ \\
\cline { 2 - 7 } & reasoning & 2 & 3 & $84.62 \%$ & $21.12 \%$ \\
\hline
\end{tabular}

Pada akhir bab peluang dan statistic, terdapat latihan soal. untuk mengetahui sejauh mana pemahaman siswa terhadap materi peluang dan statistic sekaligus hasil pekerjaan siswa pada latihan akhir bab sebagai bahan evaluasi guru terhadap kegiatan belajar mengajar yang telah dilaksanakan. Type latihan soal pada aspek knowing, jumlah soal pada Indonesian textbook lebih banyak dibandingkan pada chinese textbook. Pada type soal applying jumlah soal pada chinese textbook sebesar $84.62 \%$ sedangkan pada Indonesian textbook hanya sebesar $21.12 \%$. type soal applying pada indonesian textbook dapat dilihat pada gambar 2. ada 2 type soal reasoning pada bab peluang dan statistik pada chinese textbook dan 3 type soal reasoning pada Indonesian textbook. 
Analisis Buku Siswa Matematika SMA dari Indonesia dan China Pada Materi Peluang dan Statistik, Aditya Purnama,

\section{Latihan Soal 3.2}

1. Sekelompok ahli biologi merencanakan akan mengadakan penelitian untuk mempelajari serangga yang membahayakan di Sulawesi Tenggara. A merupakan kejadian bahwa mereka akan menghadapi cuaca buruk, B merupakan kejadian bahwa mereka akan menghadapi masalah dengan lembaga pemerintahan setempat, dan C merupakan kejadian bahwa mereka akan menghadapi kesulitan dengan alat-alat fotografi mereka. Tentukan 3 kejadian majemuk yang mungkin terjadi!

\section{Gambar 2. Contoh latihan soal type applying pada Indonesian textbook}

Cara penyajian soal merupakan hal yang sangat penting. Ini dikarenakan bentuk penyajian soal akan membentuk kemampuan penalaran matematis siswa. kemampuan penalaran sangat penting karena pada akhirnya, kemampuan penalaran yang telah siswa pelajari bisa diterapkan oleh siswa pada kegiatan sehari-hari. Kemampuan penalaran adalah kemampuan siswa untuk menggunakan pengetahuan yang dimiliki dengan pengetahuan yang baru dipelajari lalu menggabungkannya menjadi pengatahuan yang baru. Kemampuan penalaran juga adalah kemampuan berpikir logis dan sistematis (Hazlita, Zulkardi, \& Darmawijoyo, 2014). Dilihat dari perbandingan chinese textbook dan Indonesian textbook. Chinese textbook memiliki lebih banyak type soal reasoning dibandingkan type soal knowing. Hal ini membuat kemampuan matematis siswa china lebih baik dibandingkan dengan kemampuan matematis siswa di Indonesia. Indonesian textbook lebih fokus terhadap banyaknya soal latihan siswa. sehingga siswa lebih terbiasa menghadapi berbagai macam latihan soal. disamping itu, penguasaan siswa terhadap materi peluang dan statistic lebih mendalam. Pada chinese textbook, jumlah latihan dan pembahasan soal lebih sedikit. Terlihat berdasarkan hasil analysis, chinese textbook lebih berfokus pada pembahasan soal-soal applying dan reasoning. Soal-soal applying pada chinese textbbok dihubungkan dengan kehidupan sehari-hari siswa (gambar 3). mengarahkan siswa secara tidak langsung terhadap permasalah yang ada pada dunia nyata. Serta soal-soal type reasoning yang mengasah kemampuan berpikir tingkat tinggi siswa.

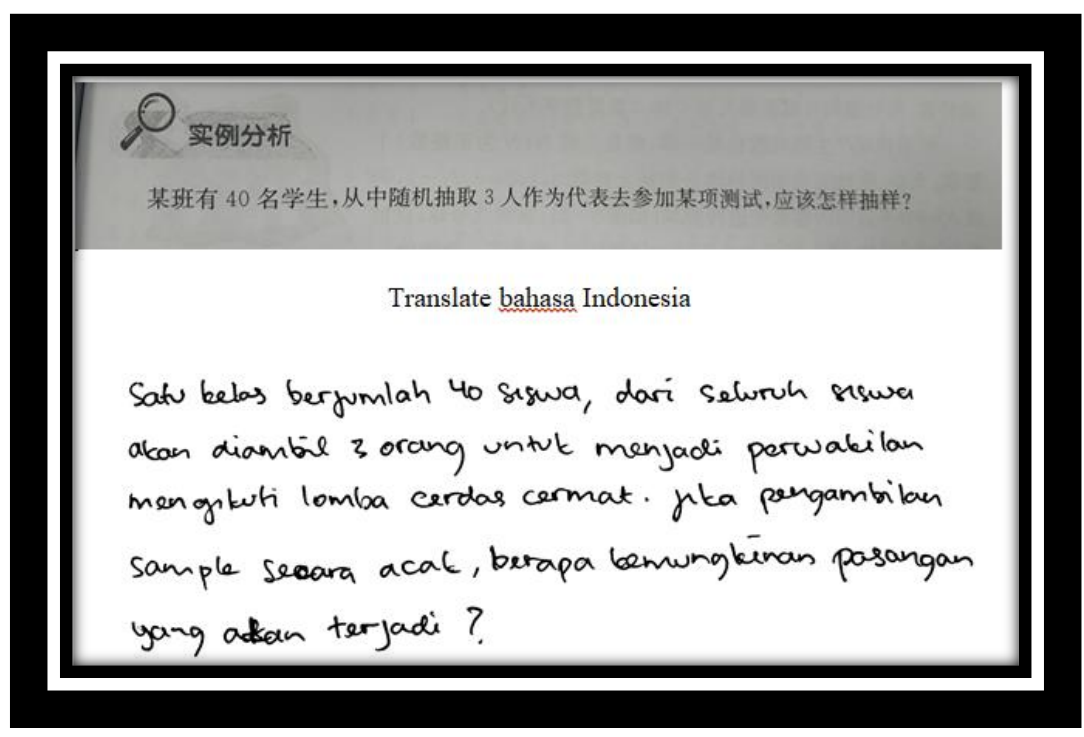

Gambar 3. Contoh latihan soal type applying pada chinese textbook 
diharapkan pembuatan buku bahan ajar dapat memperbanyak latihan soal dengan type reasoning dan applying dibandingkan dengan type soal knowing. Sehingga dapat meningkatkan kemampuan matematis siswa secara singnifikan serta siswa terbiasa berpikir dengan kemampuan tingkat tinggi (HOTS). Pada saat siswa menghadapi permasalahan pada dunia nyata, siswa juga dapat menerapkan pola pikir yang mereka telah pelajari pada kegiatan belajar mengajar di sekolah. Karena tujuan pembelajaran di sekolah sesungguhnya menyiapkan siswa untuk memecahkan masalah yang ada di kehidupan siswa pada saat ini ataupun pada saat mendatang.

\section{Analisis Jam Mata Pelajaran}

standar jam mata pelajaran mengacu pada jam kelas dasar yang diperlukan untuk menyelesaikan konten yang relevan dari buku teks. Standar kurikulum matematika China menyatakan: pengajaran probabilitas membutuhkan 19 jam kelas, statistik 27 jam kelas, total 46 jam kelas; standar kurikulum matematika di Indonesia pengajaran probabilitas 36 jam kelas dan statistik 24 jam kelas, total 60 jam kelas. Dapat dilihat bahwa jumlah jam yang dihabiskan dalam buku teks statistik probabilitas Indonesia 1,5 kali lipat dari China. Siswa di Indonesia memiliki lebih banyak waktu untuk memahami materi dan konsep yang baru diajarkan. Hal ini menjadi kesempatan bagi siswa di Indonesia untuk lebih mendalami materi peluang dan statistik.

\section{KESIMPULAN}

Analisis materi peluang dan statistik pada penelitian ini dapat menjadi referensi pada saat menyusunan buku di kurikulum baru yang akan dating. Disamping itu, isi pembahasan konten dan analisis butir soal dapat menjadi acuan ara guru pada saat pemberian soal latihan kepada siswa untuk meningkatkan kemampuan matematis dan tingkat berpikir yang lebih mendalam. Ada beberapa keterbatasan dalam penelitian ini. Pertama peneliti hanya meneliti 1 buku pada setiap Negara. Meskipun buku tersebut adalah buku yang sering digunakan di Negara tersebut, tetapi tidak menutup kemungkinan bahwa hasil penelitian ini mencakup seluruh analisis dan content pada seluruh buku yang ada pada suatu Negara. Kedua, pada penelitian ini, peneliti tidak meneliti bagaimana guru di kelas menggunakan textbook tersebut. meskipun textbook mempunyai peran penting dalam kegiatan belajar mengajar, tetapi kita semua tahu bahwa setap guru mempunyai cara caranya tersendiri untuk mengajar dan factor keberhasilan belajar siswa tidak hanya dari textbook yang mereka pakai. Textbook hanya menjadi salah satu factor pembantu dalam kegaiatan belajar mengajar dan pencapaian hasil belajar siswa.

Pada akhir kata, tidak ada kata sempurna untuk sebuah buku. Content textbook selalu berkembang dan mengikuti perkembangan jaman. Pembuatan textbook yang baik adalah yang mengarahkan siswa kepada penuasaan konsep dan pemahaman materi yang mendalam. Untuk mencegah siswa cepat lupa atau hanya menghafal rumus saja. Selanjutnya, usaha yang dilakukan seorang guru adalah untuk menggabungkan kegiatan belajar mengajar di kelas dengan menggunakan 
Analisis Buku Siswa Matematika SMA dari Indonesia dan China Pada Materi Peluang dan Statistik, Aditya Purnama,

buku dan teknologi. Pada penelitian selanjutnya dapat dilakukan penelitian pada: (1) bagaimana cara guru di Indonesia dan china menggunakan mathematics textbooks pada kegiatan belajar mengajar? 2) bagaimana textbook di Indonesia dan china mempunyai pengaruh pada kemampuan matematis siswa? penelitian selanjutnya dapat pula dilakukan analisis di setiap bab mata pelajaran matematika dari SD sampai SMA.

\section{DAFTAR PUSTAKA}

Andini, D., Mulyani, N., Wijaya, T., \& Supriyati, D. (2018). Meningkatkan Kemampuan Komunikasi Matematis Dan Self Confidence Siswa Menggunakan Pendekatan PBL Berbantuan Geogebra. Jurnal Derivat: Jurnal Matematika Dan Pendidikan Matematika, 5(1), 82-93.

Dini, M., Wijaya, T. T., \& Sugandi, A. I. (2018). Pengaruh Self Confidence Terhadap Kemampuan Pemahaman Matematik Siswa Smp. Jurnal Silogisme, 3(1), 1-7.

Fachrudin, A. D., Widadah, S., \& Kusumawati, I. B. (2019). Pre-service mathematics teachers' knowledge, beliefs, and attitude toward using PISA-based problem in mathematics education. Journal of Physics: Conference Series, 1200(1). https://doi.org/10.1088/17426596/1200/1/012013

Faelasofi, R. (2017). Identifikasi Kemampuan Berpikir Kreatif Matematika Pokok Bahasan Peluang. Jurnal Edumath, 3(2), 155-163.

Hazlita, S., Zulkardi, \& Darmawijoyo. (2014). Jurnal Penelitian dan Evaluasi Pendidikan. Jurnal Penelitian Dan Evaluasi Pendidikan, 5(2), 170-179.

Hidayat, W. (2017). Adversity Quotient Dan Penalaran Kreatif Matematis Siswa Sma Dalam Pembelajaran Argument Driven Inquiry Pada Materi Turunan Fungsi. KALAMATIKA Jurnal Pendidikan Matematika, 2(1), 15. https://doi.org/10.22236/kalamatika.vol2no1.2017pp15-28

Hutajulu, M., Wijaya, T. T., \& Hidayat, W. (2019). the Effect of Mathematical Disposition and Learning Motivation on Problem Solving: an Analysis. Infinity Journal, 8(2), 229. https://doi.org/10.22460/infinity.v8i2.p229-238

Kulsum, S. I., Hidayat, W., Wijaya, T. T., \& Kumala, J. (2019). Analysis on high school students' mathematical creative thinking skills on the topic of sets. Jurnal Cendekia : Jurnal Pendidikan Matematika, 03(02), 431-436. https://doi.org/https://doi.org/10.31004/cendekia.v3i2

Ramelan, M., \& Wijaya, A. (2019). A Comparative Analysis of Indonesian and Singaporean Mathematics Textbooks from the Perspective of Mathematical Creativity: A Case Statistics and Probability. Journal of Physics: Conference Series, 1320(1). https://doi.org/10.1088/17426596/1320/1/012037

Takeuchi, H., \& Shinno, Y. (2020). Comparing the Lower Secondary Textbooks of Japan and England: a Praxeological Analysis of Symmetry and Transformations in Geometry. International Journal of Science and Mathematics Education, 18(4), 791-810. 
https://doi.org/10.1007/s10763-019-09982-3

Tan, S., Zou, L., Wijaya, T. T., Suci, N., \& Dewi, S. (2020). Improving student creative thinking ability with problem based learning approach using hawgent. Journal on Education, 02(04), 303-312.

Wijaya, T. T., Purnama, A., \& Tanuwijaya, H. (2020). Pengembangan Media Pembelajaran Berdasarkan Konsep Tpack pada Materi Garis dan Sudut Menggunakan Hawgent Dynamic Mathematics Software. JPMI - Jurnal Pembelajaran Matematika Inovatif, 3(3), 205-214. https://doi.org/10.22460/jpmi.v1i3.205-214

Wijaya, T. T., Sukma, M., Purnama, A., \& Tanuwijaya, H. (2020). Pengembangan media pembelajaran berbasis tpack menggunakan hawgent dynamic mathematics software. Journal of Elementary Education, 03(03), 64-72.

Wijaya, T. T., Ying, Z., Cunhua, L., \& Zulfah. (2020). Using vba learning media to improve students ' mathematical understanding ability. Journal On Education, 02(02), 245-254.

Wijaya, T. T., Ying, Z., \& Purnama, A. (2020a). The empirical research of hawgent dynamic mathematics technology integrated into teaching. Journal Cendekia: Jurnal Pendidikan Matematika, 04(01), 144-150.

Wijaya, T. T., Ying, Z., \& Purnama, A. (2020b). Using Hawgent Dynamic Mathematics Software in Teaching Trigonometry. International Journal of Emerging Technologies in Learning, 15(10), 215-222. https://doi.org/10.3991/ijet.v15i10.13099

Yang, D. C., \& Sianturi, I. A. (2017). An Analysis of Singaporean versus Indonesian textbooks based on trigonometry content. Eurasia Journal of Mathematics, Science and Technology Education, 13(7), 3829-3848. https://doi.org/10.12973/eurasia.2017.00760a

Yang, D. C., Tseng, Y. K., \& Wang, T. L. (2017). A comparison of geometry problems in middlegrade mathematics textbooks from Taiwan, Singapore, Finland, and the United States. Eurasia Journal of Mathematics, Science and Technology Education, 13(7), 2841-2857. https://doi.org/10.12973/eurasia.2017.00721a

Yi, L., Ying, Z., \& Wijaya, T. T. (2019). The Trend of Mathematics Teaching Method Has Change From Fragments To Systematics. Journal Cendekia: Jurnal Pendidikan Matematika, 3(2), 471480. https://doi.org/10.31004/cendekia.v3i2.137 